\title{
Dermoscopic Demonstration of Darier Sign
}

\author{
Sweta Mukherjee ${ }^{1}$, Shekhar Neema ${ }^{2}$, Preema Sinha ${ }^{2}$, Sunmeet Sandhu², A.W. Kashif ${ }^{3}$, S. \\ Radhakrishnan $^{2}$
}

\begin{abstract}
1 Department of Pediatrics, Command Hospital, Pune, India 2 Department of Dermatology, Armed Forces Medical College, Pune, India 3 Department of Pathology, Armed Forces Medical College, Pune, India
\end{abstract}

Key words: Darier sign, mastocytosis, dermoscopy, dermatoscopy

Citation: Mukherjee S, Neema S, Sinha P, Sandhu S, Kashif AW, Radhakrishnan S. Dermoscopic demonstration of Darier sign. Dermatol Pract Concept. 2021;11(1):e2021114. DOI: https://doi.org/10.5826/dpc.1101a114

Accepted: June 1, 2020; Published: January 29, 2021

Copyright: @2021 Mukherjee et al. This is an open-access article distributed under the terms of the Creative Commons Attribution License BY-NC-4.0, which permits unrestricted noncommercial use, distribution, and reproduction in any medium, provided the original author and source are credited.

Funding: None.

Competing interests: The authors have no conflicts of interest to disclose.

Authorship: All authors have contributed significantly to this publication.

Corresponding author: Shekhar Neema, MD, FEBDV, Department of Dermatology, Armed Forces Medical College, Pune, India. Email: shekharadvait@gmail.com

\section{Case Presentation}

A 9-month-old child presented with a 3-month history of a solitary hyperpigmented plaque having a leathery surface and a peau d'orange appearance located on the inner aspect of left forearm (Figure 1A), dermoscopically characterized by a pigment network on a yellow background (Figure 1B). Urtication of the lesion upon scratching (Darier sign) was evident (Figure 1C) and decreased pigment network density and yellow hue intensity on dermoscopy. (Figure 1D). Histopathology was consistent with mastocytoma (Figures 1, E and F).

\section{Teaching Point}

Darier sign is only seen in $50 \%$ of cases of mastocytomas on clinical grounds [1]. Dermoscopic features of mastocytosis include light brown blots, pigment network, reticular vascular pattern and yellow-orange blots [2]. Pigment network and yellow-orange blots histopathologically correspond to basal layer hyperpigmentation and dense mast cell infiltrate, respectively. Eliciting Darier sign points to degranulation of mast cells which leads to erythema and edema that in turn cause decrease in a yellowish hue and pigment network intensity along with appearance of peripheral erythema on dermoscopy. 


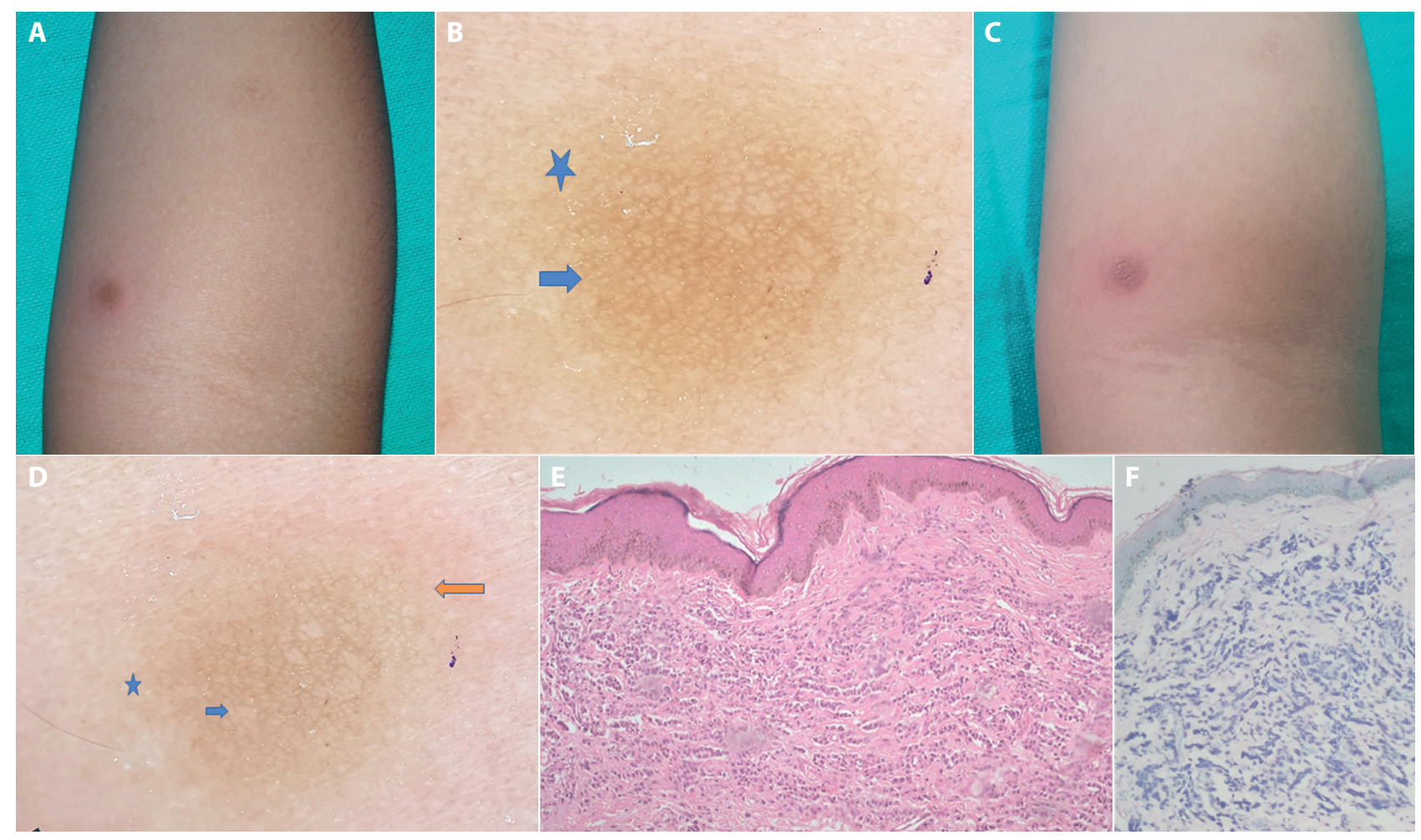

Figure 1. (A) Solitary plaque measuring $1 \times 1 \mathrm{~cm}$ over the inner aspect of forearm. (B) Polarized dermoscopy shows pigment network (blue arrow) on a yellow background (blue star) (DermLite DL4, $\times 10$ ). (C) Same plaque after eliciting Darier sign: plaque has become more well-defined, surface appears like orange-peel, and surrounding skin is erythematous. (D) Polarized dermoscopy after eliciting Darier sign shows decrease in intensity of yellow hue (blue star), decreased density of pigment network (blue arrow), and surrounding erythema (orange erythema). The pigment network is broader compared to Figure 1C due to edema in papillary dermis (DermLite DL4, $\times 10$ ). (E) Histopathology shows hyperpigmentation of basal layer $(\mathrm{H} \& \mathrm{E}, \times 4)$ and $(\mathrm{F})$ presence of mast cells in the papillary and reticular dermis $(\mathrm{H} \& \mathrm{E}, \times 4$; toluidine blue stain $\times 10)$.

\section{References}

1. Valent P, Akin C, Metcalfe DD. Mastocytosis: 2016 updated WHO classification and novel emerging treatment concepts. Blood. 2017;129(11):1420-1427. DOI: 10.1182/blood-2016-09-731893. PMID:2803118.0
2. Vano-Galvan S, Álvarez-Twose I, De las Heras E, et al. Dermoscopic features of skin lesions in patients with mastocytosis. Arch Dermatol. 2011;147(8):932-940. DOI: 10.1001/archdermatol .2011.190. PMID: 21844452. 